\title{
2017 Joint Policy Board for Mathematics Communications Awards
}

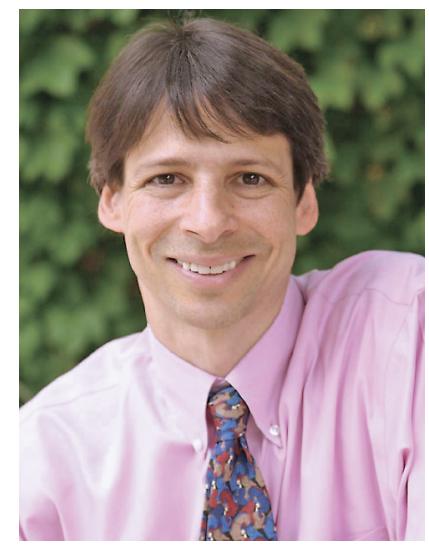

Arthur Benjamin

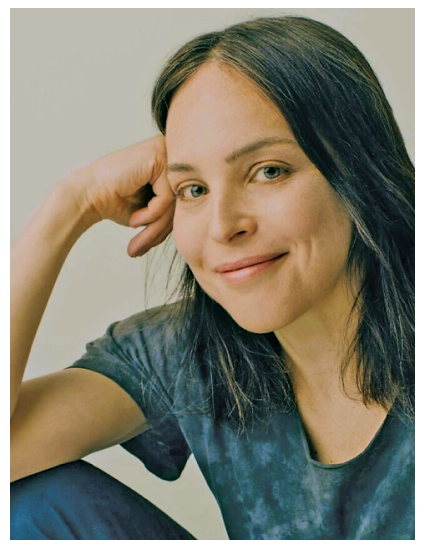

Siobhan Roberts

Two Communications Awards of the Joint Policy Board for Mathematics (JPBM) were presented at the Joint Mathematics Meetings in Atlanta, Georgia, in January 2017.

ARTHUR BENJAMIN received the JPBM Communications Award for Public Outreach, and SIOBHAN ROBERTS was presented the Award for Expository and Popular Books. The JPBM Communications Award is presented annually to reward and encourage journalists and other communicators who, on a sustained basis, bring mathematical ideas and information to non-mathematical audiences. JPBM represents the American Mathematical Society, the American Statistical Association, the Mathematical Association of America, and the Society for Industrial and Applied Mathematics. The award carries a cash prize of US $\$ 1,000$.

\section{Citation: Arthur Benjamin}

The 2017 JPBM Communications Award for Public Outreach is given to Art Benjamin for his books aimed at general audiences, his TED Talk on "mathemagic," and his popular "Great Courses" for the Teaching Company. Arthur Benjamin's work demonstrates his ability and commitment to share the joy of mathematics and excites and engages audiences at all levels.

DOI: http://dx.doi.org/10.1090/noti1525

\section{Biographical Sketch of Arthur Benjamin}

Arthur Benjamin earned his BS in applied mathematics from Carnegie Mellon and his $\mathrm{PhD}$ in mathematical sciences from Johns Hopkins University. Since 1989, he has taught at Harvey Mudd College, where he is the Smallwood Family Professor of Mathematics and past chair. In 2000, he received the Haimo Award for Distinguished Teaching of the Mathematical Association of America, and he served as the MAA's Pólya Lecturer from 2006 to 2008.

His research interests include combinatorics and number theory, with a special fondness for Fibonacci numbers. Many of these ideas appear in his book (coauthored with Jennifer Quinn), Proofs That Really Count: The Art of Combinatorial Proof, published by MAA. In 2006, that book received the Beckenbach Book Prize of the MAA. Professors Benjamin and Quinn were the editors of Math Horizons magazine from 2004 through 2008.

Benjamin is also a magician who performs his mixture of math and magic to audiences all over the world, including the Magic Castle in Hollywood. He has demonstrated and explained his calculating talents in his book and DVD course, Secrets of Mental Math, and on numerous television programs, including the Today Show, CNN, and the Colbert Report. He has been featured in Scientific American, Omni, Discover, People, Esquire, The New York Times, The Los Angeles Times, and Reader's Digest. He has given three TED talks, which have been viewed over twelve million times. Princeton Review recently profiled him in the book The Best 300 Professors. Reader's Digest calls him “America's Best Math Whiz." His newest book is called The Magic of Math: Solving for X and Figuring Out WhY.

\section{Response from Arthur Benjamin}

I am deeply humbled to be selected for this prize. Nearly all of the previous recipients of this award are heros of mine, and it is truly an honor to be recognized among such a distinguished group.

I have loved numbers all of my life. As a kid, I marveled at the fact that you could do an arithmetic problem many different ways and, if you were careful, you would always get the same answer. I found that consistency of math to be absolutely beautiful then, and I still do today. As a professor, I encourage my students to solve problems or 
prove theorems in multiple ways to build a deeper understanding of the subject.

In my classes, my writing, and my public appearances, I try to emphasize the fun and magical side of mathematics, and I would love to see more of this appear in the precollege curriculum. Since students have such easy access to powerful computational tools, we can and should replace some of the more laborious parts of our curriculum with math that is more relevant or elegant.

I would not have received this award without the support and inspiration of many people. I would like to thank my parents for encouraging me to pursue my mathematical and magical passions. I owe a debt of gratitude to Martin Gardner for setting such a high standard. Thanks to the MAA for spreading the joy of mathematics through its publications and activities. I will always cherish my work with Jennifer Quinn for our collaboration on articles and books and for being my coeditor of Math Horizons. I am so grateful to my students and colleagues at Harvey Mudd College who make it a joy to come to work every day. Last but not least, I thank my wife Deena and daughters Laurel and Ariel for their love, for their support, and for adding so much magic to my life.

\section{Citation: Siobhan Roberts}

The 2017 JPBM Communications Award for Expository and Popular Books is presented to Siobhan Roberts for her engaging biographies of eminent mathematicians and articles about mathematics that are appreciated by the general public and scientific audiences alike. The acclaimed biographies King of Infinite Space (about H. S. M. Coxeter) and Genius at Play (about John Horton Conway) bring her subjects to life and make the importance of their mathematical accomplishments accessible to all.

\section{Biographical Sketch of Siobhan Roberts}

Siobhan Roberts is an award-winning science journalist and biographer based in Toronto, Canada. Siobhan writes for the New Yorker's "Elements," Nautilus, and Quanta, and at various times has contributed to the Guardian, Smithsonian, The New York Times, Science Times, The Globe and Mail, and The Walrus, among other publications. She is an occasional Director's Visitor at the Institute for Advanced Study in Princeton.

While writing her latest book, Genius at Play: The $\mathrm{Cu}$ rious Mind of John Horton Conway, she was a Fellow at the Leon Levy Center for Biography at the City University of New York Graduate Center in New York City. Her first book, King of Infinite Space: Donald Coxeter, The Man Who Saved Geometry, won the Euler Prize for expanding the public's view of mathematics. She also wrote and produced a documentary film about Coxeter, The Man Who Saved Geometry, for TV Ontario's The View from Here.

\section{Response from Siobhan Roberts}

Writing, like mathematics, is about discovery: following one's curiosity; questioning; persevering through the "stuckedness" with an iterative process of trial and error to reach a desired (or altogether unexpected) destination.
Writing about mathematics and science is double the fun, especially since my background is predominantly in the arts. It's a serious enterprise with a steep learning curve, especially in these beleaguered times, when the Oxford English Dictionary declares "post-truth" the word of the year. "Tell all the truth but tell it slant..." wrote Emily Dickinson-it's a gradual, circuitous process finding "the Truth's superb surprise." Now we need to persevere in our efforts to tell it straight. I am honored to receive the JPBM Communications Award, and I look forward to many more mathematical adventures.

Previous recipients of the JPBM Communications Award are:

- James Gleick (1988)

- Hugh Whitemore (1990)

- Ivars Peterson (1991)

- Joel Schneider (1993)

- Martin Gardner (1994)

- Gina Kolata (1996)

- Philip J. Davis (1997)

- Constance Reid (1998)

- Ian Stewart (1999)

- John Lynch and Simon Singh (special award, 1999)

- Sylvia Nasar (2000)

- Keith J. Devlin (2001)

- Claire and Helaman Ferguson (2002)

- Robert Osserman (2003)

- Barry Cipra (2005)

- Roger Penrose (2006)

- Steven H. Strogatz (2007)

- Carl Bialik (2008)

- George Csicsery (2009)

- Marcus du Sautoy (2010)

- Nicolas Falacci and Cheryl Heuton (2011)

- Dana Mackenzie (2012)

- John Allen Paulos (2013)

- Danica McKellar (2014)

- Nate Silver (2015)

- Museum of Mathematics (Public Outreach) and Simon Singh (Expository and Popular Books) (2016)

-JPBM Announcement

\section{Photo Credits}

Photo of Arthur Benjamin is courtesy of Arthur Benjamin. Photo of Siobhan Roberts is by Christopher Wahl. 